12 JODEM: Journal of Language and Literature, vol. 10, no. 1, issue 12, 2019/2076BS

\title{
Exploration of Gender Role in Bisheshwar Prasad Koirala's Tinghumti
}

\author{
Asmita Bista
}

\begin{abstract}
Bisheshwar Prasad Koirala's novel Tinghumti is always tempting for the reader as it still reflects the relevant picture of Nepali society. In this novel the characters defy as well as define the gender roles. Influenced with revolutionary thought they defy the prescribed gender roles; but chained in age old thought they, time and again, define the traditional gender role. This article aims to identify the reasons that drive these characters to defy and define the traditional gender roles. For that Judith Butler's and Connell's idea of gender theory has been used. The significance of this study is to contribute a different perspective for the reader to see the novel Tinghumti showing that traditional gender roles are meddled and confirmed in it. The study concludes that in the novel, the characters defy as well as define the socially prescribed gender role because gender is socio-political construction that achieves legitimacy and naturality via perpetual observation and repetition.
\end{abstract}

Keywords: Gender role, performativity, character, novel, feminity, masculinity.

\section{Koirala's Presence in Nepali Literature: An Introduction}

Through his incredible literary skill Bisheswor Prasad Koirala enriched the Nepali literature. Koirala contributed to Nepali literature by highlighting the prominent issues of the then society. In fact, in his literary creations he depicted the condition of Nepali people and their struggle to claim their existence against the circumstances. While depicting people's struggle, he beautifully explored the human psyche. Therefore, his literary creations present the psyche of the whole society and human community. Krishnahari Baral and Netra Atom assert that Koirala is a famous gleam of Nepali literature who artistically presents psychology and philosophy in the field of novel (208). They observe Koirala's expertise in various genres and they claim that Koirala started his literary career with story writing. Then, he explored his career on writing novel, poetry, and autobiography. He did several experiments in his novels and moved forward his novelistic career expressing his thought in the guise of art. Likewise, he gave importance on subject-wise and setting-wise variation in his novels.

Koirala has made each of his novels unique because he has explored vivid subject matters in his novels. Apart from this, since his novels are loaded with philosophical thought, his 
novels have got the special space in Nepali literary field. Gyanu Pandey posits that while going through his literary creations, the readers find Koirala as a highly intellectual thinker (91). In her view, Koirala presented a deep thought about National issues and the issues related to the human freedom. Similarly, highlighting Koirala's writing style, Rajendra Subedi points out that though Koirala's novels are small in size, they have inaugurated the exploration of human psyche. Subedi claims that Koirala has become a mid-point of three specialties in the literary field. They are: reflection of existentialism, psychological identification of women's nature, and use of sexuality. In his novels, he has shown how these three specialties draw the people's attention (384). Apart from this, in Subedi's view, Koirala has appeared as a precursor of gender equality as his female characters are strong, and intelligent. Similarly, Gyanu Pandey claims that in his novels, Koirala has raised questions on the patriarchally established values (78). She observers that Koirala's novels have shown that the imposition of patriarchal values is a great restriction to human freedom.

\section{Problem, Objectives, and Methodology}

The plot of Tinghumti revolves around its central character Indramaya whose life gets changed with the political revolution against the Panchayat system. Since Indramaya is an educated and conscious lady, she cannot stick to the traditional gender role forever. Rather, she denounces the socially prescribed gender role which caused great upheavals in her life. Like Indramaya, her husband Pitambar and her lover Ramesh also do not remain in the traditional gender role. Though these characters belong to the stark patriarchal society which forces them to perform in a masculine way, they time and again fail to showcase their masculinity because education, political consciousness and circumstances weaken their manliness. Consequently, they cannot confine into traditional gender role. Nevertheless, under the social pressure and the traditional mindset they knowingly and unknowingly perform the traditional gender roles. So, in such a condition, whether their life get affected or not is the basic problem of this study. To find it out, this article answers the following research questions:

- What are the problems the characters face while confining into the traditional gender roles?

- Why do these characters fail to remain rigid in the prescribed gender role?

- How do they lead their life in such situations?

To find out the reasons the researcher analyses the activities and motives of these characters in the light of Connell's idea of masculinity and Judith Butler's performitive theory. In 1980s theorizing about gender became the center of a new phase of critical study because "some feminists manifested a shift in focus from feminist studies to gender studies" (Smith npag). Focusing on the reason of the flourishment of this newly emerged area of study, Imelda Whelehan and Jane Pilcher claim that Gender theorists show their concern on inequality and 
differences, not just between genders but within genders, based on class, sexuality, ethinicity, age, dis/ability, nationality, religion, and citizenship status (xii). Likewise, Felluga and Allen express the similar thought on the thrive of gender theory and argue that since gender theorists utilize the strategies of other critical schools in their analysis of gender and sex and have been divided into different sub-schools that interweave the insights of disparate approaches this newly-emerged area of study flourished (cla.purude.edu). For these theorists masculinity and feminity are socially invented, constructed categories which have particular meanings that vary across different cultures and different time periods.

Gender theorists present a new way of looking at sex and gender. Judith Butler posits that gender should be regarded as a flexible and fluid variable, rather than a fixed binary system constituted by male and female opposites. Butler posits: "identity is performatively constituted by the very expressions that are said to be its results" (25). For Butler, gender is not a central part of people's identity, but a performance that varies according to different times and different situations. She argues that identity is seen free-floating and regulating. So, her innovative approach to gender identity allows a person to shape and construct his or her own individual identity. Butler's theorization about "gender performativity" reveals that our bodies are not fundamentally and intrinsically sexed; they "become sexed through a continual process of acting and re-enacting certain gendered roles; this repetition occurs within a hegemonic system that shapes the very possibilities of the roles we can enact" (quoted in Payne and Barbera 270). She claims that if the creation of the sexed being comes from repeatedly enacting certain social norms, we may be able to knowingly disrupt the system by acting against those norms. Affirming Butler's idea, Susan S. Lanser claims that gender has a constructed status which is fashioned through culture. According to Lancer, "gender is a means of identifying a male or female identity by drawing on cultural codes that conventionally signify masculinity or feminity (216). Likewise, Connell recognizes that masculinity is socially constructed through performances. He claims that masculinities are not fixed character types but configurations of practice generated in particular situations in a changing structure of relationships (81). These theorists posit that masculinity and feminity are not inherent properties of individual; rather, they are inherent or structural properties of the society. Therefore, they both condition and arise from social action.

\section{Critics' Perspectives in Tinghumti: A Review of Literature}

B.P. Koirala's literary creations are reviewed from various perspectives since their publications. They still draw critics' attention for its freshness in subject matter, unique presentation, and lucid style. Critic Indra Bahadur Rai praises Tinghumti's plot, its presentation, and theme and posits that the unique presentation of these novelistic elements has made this novel special. He points out that the plot of this novel is based on the three decisions taken by 
Indramaya in three stages of her life that take her life into three different directions (251). In Rai's view, Indramaya's decisions help her to realize her existence in the world. He further claims that Tinghumti has explored the philosophy of existentialism. He posits that the major characters of this novel struggle for existence; the characters try to establish their existence by taking decisions individually. In his view, through the novels Koirala has shown how and why the people struggle for existence.

Similarly, Krishnahari Baral and Netra Atom observe that Koirala's first novel Tinghumti has portrayed the struggle of Indramaya, the central character, for her freedom and existence. They point out that the novel portrays the struggle of Indramaya in the three stages of life. It exposes that being a conscious woman, she takes her decision as a beloved, wife, and mother (209). They further posit that Koirala's novels are the field of experiment of psychological facts; so, in Tinghumti, he has presented complications of Indramaya's sexual desire. They view that Koirala has explored the psyche of the characters and has shown that Indramaya's unusual justification about her sexual relationship to Ramesh is outcome of her unsatisfied sexual desire. Likewise, in critic Rajendra Subedi's view, Tinghumti is successful to expose the aspect of truth in our life in a realistic way (385). He praises Koirala's incredible skill of the presentation of ordinary story in very extraordinary way. Likewise, he claims that the story of this novel has become timeless as it has depicted the human sentiments.

In the same vein, Gyanu Pandey has praised Tinghumti for its theme and subject matter. Analyzing Tinghumti from the perspective of gender theory, Pandey highlights the causes behind the characters' suffering and concludes that the influence of patriarchal ideology is the main cause of their sufferings. She claims that Tinghumti has explored the social issues, particularly the gender issue. Likewise, Koirala's novelistic style has been highly praised in the editorial of Tinghumti. It mentions that Koirala's writing style, use of language, sentence structure, and literary craft seem to be quite different than that of other contemporary writers (npag). The editor claims that this novel appeared as a landmark of Koirala's literary career. The critics find Tinghumti a powerful novel because though to discuss people's psyche was not so familiar matter in the then society, Koirala dared to explore the human psyche in this novel.

Likewise, for Bishnu Kumar Khatri, Tinghumti can be taken as a social and historical document as it has portrayed the historical events of the then society. He claims that this novel consists of the subject matters such as political background of contemporary Nepali society, social discrimination based on cast system, sexual psychology of men and women, the consciousness of human existence and so on (73). These critics have analyzed Tinghumti from various perspectives and have highly praised its unique structure, themes and presentation. Nevertheless, they have left the scope to analyze it from the perspective of Connell's and Butler's idea of gender theory. 


\section{Challenging the Traditional Gender Role}

In Tinghumti, B.P. Koirala has presented the story from the perspective of Indramaya. The novel portrays Indramaya's pains and sufferings highlighting the contemporary social background that reserve injustice, and pain for her in the form of gender inequality. Indramaya goes through several obstacles in her life but she boldly faces them dismantling the image of a weaker sex. As an educated woman she believes in the choice of freedom; therefore, she takes all the decisions of her life without others' interference, no matter they are her parents or her husband. The current political movement and the thrust of change among the people implant seeds of revolution in Indramaya. Therefore, in the quite young age she defies the prescribed gender role though she is aware about its apparent result.

In Tinghumti, Koirala has presented Indramaya as a thoughtful woman. The narrator portrays her: "jatisukai sundara tathaa chanchala baalikaa bhae pani usamaa chintanashilataako abhaava thiena [Though she was very beautiful and agile, she was intelligent and thoughtful, too]" (4). Indramaya's thoughtfulness and assertiveness denounce the social categorization of women pointed out by Alice H. Eagly that women are more likely to be categorized as communal (qualities that are described by selflessness, concern for others, and desired to be at one with others) and men are more likely to be categorized as agentic (qualities that are described by self-assertion, self-expansion, and the urge to master) (16). When she falls in love with Pitambar she does not hesitate to tell her mother about her choice and defy the traditional gender role that confines the woman into the guise of shyness. Thus, she challenges the social obligation for women to suppress their desire. Moreover, she chooses Pitambar as her life partner who is inferior to her in socio-economic status. Indramaya knows that in Nepali society, husband should belong to the higher social status so that he can maintain his position at the top of familial hierarchy. Denouncing this fact, she chooses Pitambar, a poor and ordinary man, as her husband though she belongs to a rich and prestigious family. Moreover, her family has connection to the royal family, the power center. By accepting Pitambar as her husband, she challenges the traditional belief of people regarding the choice of husband.

Though the gender roles prescribed to women by patriarchy are "the ones of an obedient daughter" and they call "for particular qualities, thought to be naturally feminine, such as patience, emotion and self-sacrifice" (Weedon 3), Indramaya believes to follow her own whims and fancies. So, when her parents try to impose their decision about her life partner, she revolts in her own style. She confines herself into the house. Thus, she tries to make her parents surrender to her decision. Defeating her mother in debate about the choice of her husband, she strongly asserts: if as a rebellion, Pitambar's life was in danger, instead of leaving him and commencing a new life with a person chosen by her parents, she should accompany and 
support him (6). Though women have been presented as a 'saved' and men as a 'savior', Indramaya's view reverses this belief. Therefore, she leaves her parents' home and marries Pitambar. Not only that, ignoring the societal expectation, she takes the initiation for the commencement of her conjugal life affirming Butler's claim that "if the creation of the sexed being comes from repeatedly enacting certain social norms, we may be able to knowingly disrupt the system by acting against those norms (179). Thus, she completely defies the prescribed gender role by taking the first decision of her life.

In the novel, Indramaya consistently claims her powerful presence among the male counterparts. The political environment of her new home sharpens her intellect and boosts up her confidence. She is as educated as the political activists who gather in her house to discuss about their plan against the autocratic king and Panchayat regime. She is also conscious about the political condition of the country. So, she takes part in the thoughtful debate about the political movement with them. Moreover, she questions on their immature decision and present the rational solution for the complicated political issues. Apart from this, she becomes the support system of their political movement as well. She constantly defies the traditional gender role of a demure, irrational, meek wife and takes the role of an assertive, wise and rational political activist. Thus, she affirms Butler's claim that "gender is performatively produced and compelled by the regulatory practices of gender coherence" (34). Indramaya gets chance to involve in intellectual and risky activities that bring her out from the conventional gender role.

Indramaya demonstrates courage and rationality when her husband is sent to jail as a political activist. After his arrest, she becomes alone and destitute. She cannot get help from anywhere. Her parents also deny helping her. Even in such difficulties, she faces the situation wisely and boldly. First of all, she tries to get support from her parents. When they deny helping her, she sells her gold earring and manages to survive in a stark scarcity. Then, she goes to find out about Pitambar's condition: She visits the magistrate. When she cannot get any information there about Pitambar, she visits the commissioner. She fails to get any kind of helps from him, too. Still, she does not give up; and then visits the army head quarter. But there the security guard stops her at the main entrance (30). Despite the failure in her every attempt, she keeps on trying. She writes petition on the supreme authorities. Showcasing her shrewdness, and audacity, she falsifies the label given to women as an irrational and weak.

Gender theorists claim that gender activities and sexual orientations are not innate but are constructed. For them masculine and feminine vary from time to time and place to place. Connell argues: "Gender is not an expression of biology. Rather, it is a pattern in the social arrangements, and in the everyday activities or practices which those arrangements govern" (10). Affirming Connell's claim, Indramaya practices freedom in her husband's home, mainly after his arrest. A single-member family structure provides a fertile ground to flourish her 
liberty; and she practices it over and over. When she gets attracted towards her husband's friend Ramesh, she does not hesitate to keep extramarital affair with him. It reflects her choice of freedom, as she prioritizes her happiness over social restrictions. Taking this decision, she again affirms Butler's idea that "we acquire gender through repetition" (Bodies 95). Indramaya likes to spend time in Ramesh's company; she also wants to fulfill her sexual needs. Therefore, she starts an affair with him. She feels free and acts freely.

From the beginning, Indramaya exposes the masculine characteristics: self-esteem, assertiveness, and courage. These qualities of her enhance with the passage of time as she singularly struggles against the problems. These qualities reflect in her decisions. Her decision of leaving Pitambar completely dismantles the patriarchal belief that projects women as a dependent, and a submissive person. When Pitambar gives her option to make a choice between him and her illegitimate daughter Rama, she gives him a great shock. She chooses Rama instead of him because she realizes that engulfed in patriarchal thought, Pitambar intends to objectify her. The narrator depicts Indramaya's mentality when Pitambar shows indifference towards her and insults her daughter:

Ahileko samasyaa ta usako astitwasanga sambandha raakhthyo. Aaphno astitwa lopa garaaera maatra Indramaya ahileko samasyaatarpha bimukha bhaera basna sakne thi. Pitambarako kuraa maaneko khandamaa Indramaya nai rahane thiina. [The current problem was related to her existence. Indramaya could be indifferent towards the current problem only if she extinguished her existence. Had she accepted Pitambar's proposal, Indramaya would not have existed]. (66)

Pitambar's proposal puts Indramaya's existence into question because if she accepts it, her identity changes into a slave from that of a wife. To live a slavish life is never acceptable for educated and self-esteemed Indramaya. So, she decides to leave his house. She has courage to earn livelihood for her and Rama. She even becomes ready to face the social assault. After leaving her husband's house, she works hard, works in various offices, and leads an independent and respectful life. Conflicting thought of Pitambar and his wife regarding gender equality reflect in their performances and it leads to the tragic end of their relationship.

Not only Indramaya but her husband, Pitambar, also fails to remain in the traditional gender role, in some cases. Sometimes, his masculinity also floats towards the opposite gender pole. Peter F. Murphy claims that masculinity cannot be understood as static, abstract, or essential. What have been current in literary representation of manhood, according to him, are "dominant cultural assumptions about masculinity, in a way that this representation ends up exposing the untenability of such assumption (5-6). Though male is supposed to be assertive, and courageous, in Tinghumti Pitambar lacks these attributes. He does not dare declaring his love to Indramaya. Likewise, he hesitates to take initiation of their marriage. Similarly, he cannot 
throw Indramaya out of his life and the house even though he knows about her adultery with Ramesh. He tolerates unwanted presence of Indramaya and her illegitimate daughter for two years. Moreover, he is ready to accept her incase Indramaya accepts his condition. Thus, Pitambar appears as an unassertive and weak person.

Like Pitambar, Ramesh also fails to perform the masculine attributes. Though males are expected to have courage, he acts cowardly. In Tinghumti, Koirala has presented Ramesh's coward nature in various instances. He fears from the government's punishment i.e. imprisonment to the rebellion and betrays his friends by divulging to the government about their rebellious activities against the rulers. Similarly, when Indramaya becomes pregnant out of their illegitimate relationship, instead of taking the responsibility of a father, he gradually disappears from Indramaya's life. In his seminal book Gender, Connell claims: "we cannot think of womanhood or manhood as fixed by nature. However, neither should we think of them as simply imposed from outside, by social norms or pressure from authorities. People construct themselves as masculine or feminine"(4). Masculine and feminine are not innate traits. Rather, they are imposed and fabricated. So, it takes no time for these traits to disappear from these characters in various occasions and circumstances.

\section{Negotiating to the Prescribed Gender Role}

Butler's theory claims that gender is a corporeal style, a copy of a copy. She argues that people who fail to 'do' their gender correctly, or who do it in ways that accentuate its genealogy and construction, are punished by culture and laws (273). In Tinghumti, whenever Indramaya fails to do her gender correctly i.e. claims her freedom and chooses Pitambar her husband, the society punishes her. Her parents boycott her from the family. Likewise, being pressurized by their parents, her friends also break the friendship with her. Indramaya recalls her father's words: "Indramaya marisakeki chha. Nagara tesakaa kuraa. [Indramaya has already died. Do not mention her name]". She also hears that though her friends want to visit her, their parents prohibited them to see her as they urge: "tyo besekaa najaanu [Do not go to visit that whore]" (9-10). Challenging the traditional gender role, she faces social embargo. Nevertheless, Indramaya, time and again, exposes the feminine attributes affirming Tyson's claim: "Regardless of one's sex, one's gender identity may consist of some combination of feminine and masculine behaviors" (Tyson 115). Through her activities Indramaya affirms that masculinity and feminity are not a fixed category and therefore, does not locate in one's body as a fixed entity.

After taking the first decision of her life, following the patriarchal ideology which restricted the women to the house and hearth, Indramaya confines herself into the domesticity. Defining the prescribed gender role she tries to become a good housewife. The narrator reports her condition: "saathiharu bhelaa bhaekaa bakhata uniharuko aadarasatkaara, chiyaapaanako 
byawasthaa ra dainika grihasthiko yaawat jimmedaariko todaamodaamaa Indramaya atyanta vyasta rahanthi [Indramaya became so busy in welcoming the guests, arranging tea and snacks for them, and in other household chores, when they gathered in Pitambar's house]" (10). Similarly, Indramaya knows about the extramarital affairs of her husband; but she does not criticize him for his betrayal. Rather, she thinks that as a wife she should surrender to her husband's desire and should sacrifice herself for his happiness. Representing conservative thought she takes Pitambar's extramarital affair as a normal practice. She believes that if a husband practices it, it becomes justifiable; whereas, she feels guilty when she finds traces of love towards Ramesh. She even expects forgiveness from Pitambar for it even though she suppresses her feelings to Ramesh.

Indramaya loves Ramesh's company; but she cannot easily make physical relationship to him, despite her desire for that. The deeply seated patriarchal teaching constrains her desires and regulates her to stay loyal towards her imprisoned husband. She analyzes the reason for her hesitation: "Rameshsanga ghanisthataa sthaapita garna hunna bhanne hradayamaa jamera baseko saamaajika biswaasa ra aasthaakai eutaa rupa ho [It is actually a form of a conviction and belief imposed by the society which restrict her to keep intimacy to Ramesh]" (24). Later, she keeps sexual relationship with Ramesh; but goes through the burden of guilt for that act. She thinks that a wife should keep her desire under control at all circumstances and should not even think about another man no matter how much characterless her husband is. Connell rightly posits: "people arrange so much of their everyday business around the gendered distinctions that they hardly pay attention to normative gender patterns that underlie those distinction (4). Since she cannot justify her relation to Ramesh she starts visiting temple regularly with the hope that god may forgive her sin.

Though Indramaya fails to defy the prescribed gender role in some occasions and circumstances, her mother cannot defy the prescribed gender role even in a single occasion. To challenge the gender role is not possible for her because she belongs to the society that imprisoned women in the traditional gender role through social-religious norms and values. She exposes the patriarchal thought in all of her performances. Berger argues that women appear as a surveyed and watched entity (to themselves and to others), and Foucault's theory can be used to show that this is due to a constant socialized expectation of women, of being passive and quiet (McNay 35). Brainwashed with the patriarchal belief she restricts Indramaya to choose her life partner. Instead of trusting on the capability of her educated daughter, she thinks that Indramaya will be helpless incase her husband dies.

For Indramaya's mother, women's life is completely dependent on her husband. So, Indramaya's choice becomes unacceptable for her. Therefore, when she comes to know that Indramaya is in love with a rebellion, she worries for her. Indramaya's mother can neither be an 
authoritative mother, nor can be an assertive wife as social norms regulate her performance. Butler claims: "gender is the fabrication of compulsory frames and its social appearance is incessantly policed by the various forces in order to be stylized in a specific way" (44). She becomes helpless when Indramaya denies her suggestion. Likewise, when Indramaya elopes to Pitambar and her husband boycotts her existence, she cannot show her love to Indramaya. Governed by wifely duty, she follows her husband's declaration that they do not have any connection to Indramaya and she is dead for him. Indramaya reports her mother's condition: "Aamaa bhane aansu chuhaaunuhuntyo re-baako darale kunaamaa basera nadekhne gari [Mother used to shed tears at the corner so that my father could not see her as she fears him the most]" (9). Social norms regulates Indramaya's mother to strictly follow her husband's order. She performs what she practices in that social setting.

In Tinghumti, except Indramaya, most of the characters perform the prescribed gender roles. Pitambar and Ramesh exhibit masculine traits as it flourishes in the fertile social scenario. Connell argues: "masculinity is not a natural state, but a socially constructed, fluid, collective gender identity" (81). Pitambar exposes his authoritativeness to his wife. Since patriarchy ascertains male's dominance, Pitambar's brooding in Patriarchal surroundings, inspires him to embrace standards of manliness. Therefore, when Indramaya participates in the political debate among his friends, it hurts his male ego. Consequently, he makes sarcastic remarks on her presence in these debates: why you do not be happy when you are a single woman among these males. That is why you may think that you have become precious, no (14)? On the other hand he engages in multiple sexual relations displaying his masculinity.

Though Indramaya knows about his engagements in multiple sexual relations and feels bad for his betrayal, he ignores her reactions. Pitambar's thoughts and behaviors reveal that masculinities are not essences that individuals innately have. Rather, they occur in social relations where issues of power exist at the level of practice and structure. Since Nepali society centralizes power to the male, Pitambar exhibits power by ruling over his wife affirming Connell's claim that "masculinities are defined in culture and sustained in institutions" (11). Pitambar is conscious to approve his deeds from the society as he practices to do the same. Therefore, he goes to visit his wife in the hospital and tries to pay the expenditures of the hospital. Koirala shows that his every deeds and decisions are regulated by the social norms that obligate him to take the responsibility of his wife. Nevertheless, he becomes completely indifferent towards Rama as her birth is out of adulterous relationship of Indramaya and Ramesh. He performs as a cruel person as he compels Indramaya to abandon her infant daughter in order to get wifely position in his life. He does so because of the social back up.

From the beginning of their conjugal life, he performs as an authoritative husband and gets approval for it. Therefore, he declares his verdict on Indramaya's extramarital affair since he 
knows that her illegal relationship does not conform to the values of the ideal society. Likewise, he wants to take revenge upon his wife as he gets humiliated when she becomes a mother.

Earlier, he questions on her potentiality of becoming a mother but later he himself proves to be an impotent; thus, he gets humiliated. Therefore, he wants to punish her. He regularly insults and hurts Indramaya. Moreover, he even does not accept Rama's existence. His activities explain the impact of masculinity that sanctions cruelty and maintains status quo as men assume they have a right to intimidate, exploit and subordinate women. When the situation becomes unbearable to her, she leaves his house. This move of Indramaya does not bring any change in Pitambar's performance of masculinity. Rather, conforming his masculine traits, he remarries and spends a reputed life.

Since Tinghumti depicts the society of Panchayat time which strictly imposed the patriarchal values, most of the characters define the traditional gender role. So, like Pitambar, Ramesh also exposes masculine traits throughout the novel. Guided by patriarchal mindset he regards Indramaya as a weak and helpless person. He declares himself as Indramaya's savior when she becomes alone after Pitambar's imprisonment: Bidaa huna laagdaa maile saantwanaa dindai uhaanlaai bhetera bhaneko chuu, Indramaya bhaaujuko ma baahira gaera jimmaa linchhu, chintaa nalinuhola [At the time of parting, I met him and assured not to worry about Indramaya as I would take care of her when I would be free from the imprisonment]" (33). He exercises his patriarchal authority and interferes on Indramaya's thoughts and actions. He starts to live in her house and takes charge of her house by arranging everything to run the house. He insists her to keep sexual relationship to him because the exploitation of female is a common practice in the then society. Witnessing the oppressiveness of patriarchy and the victimization of women, he thinks that Indramaya's surrender to his desire is a normal thing. He tries to perform his masculinity in every situation affirming Jessie Bernard's claim that "since the male sex role has higher status, men attain power over women and gain control of many of society's valued rewards" (quoted in McCubbin and Dahl 194). Even though, he is a married man, he unhesitatingly keeps extra marital affair to Indramaya as by doing this he wants to showcase his manliness. He displays his masculinity till the end of their relationship by offering financial help to pregnant Indramaya.

\section{Conclusion}

The characters of the novel Tinghumti, time and again, defy the traditional gender role because being conscious and educated people, they find the socially prescribed gender roles unsuitable for them. Likewise, since they involve in the revolution, it reflects in their performance of gender roles, too. The central character, Indramaya, exhibits courage, selfesteem, and intelligence in her thought and actions because she is a conscious and educated lady. She is aware of her rights and freedom; so, she cannot follow the traditional gender role 
that constrains her right and freedom. Consequently, she acts smartly, independently and rationally. She decides to choose her life partner, ignoring the wishes of her patriarchally programmed parents who think that a girl should follow the instructions of her parents while taking the decisions of her life. Likewise, she decides to involve in political activities, to start the extramarital affair to Ramesh, and finally, to leave her husband Pitambar and to start life independently. However, despite this, for several times, she follows the traditional gender role. She tries to be a good housewife and accepts the inferior position in the family. She ignores Pitambar's insults to her because she thinks that it is her duty to be submissive to her husband. Likewise, Pitambar and Ramesh also cannot perform their manliness in several occasions. Dismantling the image of brave and assertive males, they act cowardly and unassertively in some cases. However, these characters defy the prescribed gender roles only in limited cases and circumstances. In fact, most of the time, they perform the prescribed gender roles. They perform their masculinity in several occasions as the patriarchal society regulates their thoughts and behaviors. Due to constrain of time and space, the researcher has delimited this study in the gender study. However, since Tin Ghumti is enriched with several issues, there is scope for further study using other perspectives such as psychoanalysis theory, and social realism.

\section{Works Cited}

Baral, Krishnahari and Netra Atom. Upanyaasa Sidhaanta ra Nepali Upanyaasa [Theory of Novel and Nepali Novel]. Sajha Prakasan, 2066 BS.

Butler, Judith. Bodies That Matter: On the Discursive Limits of Sex. Routledge, 1993.

---. Gender Trouble: Feminism and the Subversion of Identity. Routledge, 2007.

Connell, Raewyn. Masculinity. Polity Press, 1995.

---.Gender. Polity Press, 2002.

---. Confronting Equality: Gender Knowledge and Global Change. Polity Press, 2011.

Eagly, Alice H. Sexual Differences in Social Behavior: A Social-Role Interpretation. Psychology Press, 1987.

Felluga, Dino and Emily Allen. "General Introduction to Theories of Gender and Sex." Introductory Guide to Critical Theory. http://www.cla.purude.edu.

Khatri, Bishnukumar. "Tin Ghumti: Eka Phanko [A Round to Tin Ghumti]." Sagaramaathaa Vaanmaya. Sagarmaathaa Vaanmaya Pratishthaan, 2070 BS, pp 73-78.

Koirala, Bisheswor Prasad. Tin Ghumti [Three Modes]. 11 ${ }^{\text {th }}$ ed. Sajha Prakasan, 2071 BS.

McNay, Lois. Foucault and Feminism: Power, Gender, and the Self. Northeastern UP, 1993. 
24 JODEM: Journal of Language and Literature, vol. 10, no. 1, issue 12, 2019/2076BS

Lancer, Susan S. "Gender and Narrative" Handbook of Narratology. $2^{\text {nd }}$ ed. DeGruyter, 2014, pp. 206-18.

McCubbin, Hamilton and Barbara Blum Dahl. "Sex Roles". New Directions, Reading Writing and Critical Thinking. Edited by Peter S. Gardener. $2^{\text {nd }}$ ed. Gopsons Papers, 2009.

Murphy, Peter F. "Introduction: Literature and Masculinity." Fictions of Masculinity: Crossing Cultures, Crossing Sexualities. NYU P, 1994, pp.1-17.

Pandey, Gyanu. Nepaali Upanyaasama Laingikataa [Gender in Nepali Novel]. Nepal Pragya Pratisthan, 2069 BS.

---. "Koiralako Upanyaasamaa Bichaaratvako Saghanataa [Density of Thought in Koirala's Novels].” Sagaramaathaa Vaanmaya. Sagarmaathaa Vaanmaya Pratishthaan, 2070 BS, pp. 79-91.

Pilcher, Jane and Whelehan Imelda. 50 Key Concepts in Gender Studies. Sage Publication, 2004.

Payne, Michael and Jessica Rae Barbera. A Dictionary of Cultural and Critical Theory. Blackwell, 2010.

Rai, Indra Bahadur. Nepaali Upanyaasakaa Aadhaaraharoo[Foundations of Nepali Novels]. $3^{\text {rd }}$ edition, Abhibyakti Chhapaakhana, 2058 BS.

Smith, G. Bonnie. "Gender Theory." https://www.encyclopedia.com

Subedi, Rajendra. Nepaali Upanyaasa: Paramparaa ra Pravriti [Nepali Novel: Tradition and Tendency]. Sajha Prakasan, 2064 BS.

Tyson, Lois. Critical Theory Today: A User Friendly Guide. $2^{\text {nd }}$ ed. Routledge, 2008.

Weedon, Chris. Feminist Practice and Poststructuralist Theory. Blackwell, 1995. 